\title{
BENTUK TINDAK TUTUR PERSUASI PERAWAT DAN PASIEN DI PUSKESMAS BANUA LAWAS KABUPATEN TABALONG
}

\author{
Johan Arifin dan Lili Agustiana \\ STKIP-PGRI Banjarmasin \\ Jln. Sultan Adam Kompleks H. Iyus, No. 18 RT. 23 Banjarmasin, \\ Kode Pos 70121. \\ e-mail: johankaltara@stkipbjm.ac.id
}

\begin{abstract}
Abstrak
Pengungkapan tuturan dan tujuan dalam peristiwa berbahasa berbeda-beda. Dalam Puskesmas, tuturan antara perawat dan pasien untuk mengungkapkan maksud di balik tuturan dan memperlihatkan tindakan-tindakan. Penelitian ini bertujuan untuk mendiskripsikan fungsi tindak tutur dalam tuturan perawat dan pasien di puskesmas Banua Lawas dan mendeskripsikan bentuk persuasi yang digunakan perawat dan pasien di puskesmas Banua Lawas.

Penelitian ini menggunakan pendekatan kualitatif dengan metode deskriptif. Sumber data penelitian ini adalah tuturan perawat dan pasien, tuturan antara perawat dan pasien di puskesmas Banua Lawas Kabupaten Tabalong, dan dokumen tertulis berupa transkip tuturan antartokoh dalam tuturan perawat dan pasien puskesmas Banua Lawas. Pengumpulan data tersebut diperoleh dengan menggunakan metode simak dan diikuti dengan teknik lanjutan: teknik simak bebas libat cakap dan teknik catat.

Hasil penelitian ini adalah tuturan perawat dan pasien di puskesmas Banua Lawas Kabupaten Tabalong perawat menggunakan persuasi. Bentuk persuasi yang digunakan ialah rasionalisasi sebanyak 4 tuturan, identifikasi sebanyak tiga tuturan, sugesti sebanyak dua tuturan, konformitas sebanyak 4 tuturan, kompensasi sebanyak dua tuturan, penggantian sebanyak dua tuturan, dan proyeksi sebanyak satu tuturan.
\end{abstract}

Kata kunci: bentuk tindak tutur, persuasi

\section{Pendahuluan}

Manusia adalah makhluk individu dan makhluk sosial. Dalam hubungannya dengan manusia sebagai makhluk sosial, terkandung suatu maksud bahwa manusia bagaimanapun juga tidak terlepas dari individu yang lain. Bahasa memegang peranan penting dalam kehidupan manusia. Bahasa adalah sistem arbitrer, yang digunakan oleh para anggota suatu masyarakat untuk melakukan kerja sama, berinteraksi, dan mengidentifikasikan diri. Manusia mempergunakan bahasa sebagai sarana komunikasi vital dalam hidup ini. Bahasa adalah milik manusia, salah satu ciri pembeda utama kita umat manusia dengan makhluk lainnya di dunia. Bahasa adalah alat untuk menyampaikan pesan atau makna dari penutur kepada mitra tutur. Makna dalam komunikasi tersebut diungkapkan dengan kalimat. Mu'in (2009:16) mengatakan bahasa digunakan manusia untuk alat komunikasi dalam upaya berinteraksi dengan sesamanya.

Durdje Duraje (dalam Mu'in, 2009:21) menyatakan bahwa berbahasa yang baik adalah berbahasa yang mengandung nilai rasa yang tepat dan sesuai dengan situasi penggunanya, 
sedangkan berbahasa yang benar adalah berbahasa yang secara cermat mengikuti kaidah-kaidah yang berlaku.

Allan (dalam Nadar 2009:10) berpendapat bahwa berkomunikasi merupakan kegiatan sosial, dan sebagaiman kegiatan sosial yang lain, kegiatan berkomunikasi ini hanya akan dapat dilaksanakan apabila ada pihak lain yang terlibat. Masing-masing pihak harus bekerja sama dan memperhatikan citra lawan bicaranya. Setiap komunikasi tentunya ada dua orang atau dua kelompok orang, yaitu pengirim informasi (sender) dan penerima informasi (receiver). Informasi yang disampaikan bisa berupa ide, gagasan, keterangan atau pesan. Manusia menggunakan alat untuk berkomunikasi, setiap individu dapat menyapa, bercerita, bertanya, bahkan mengungkapkan pendapat dan sebagainya.

Pada hakikatnya wacana percakapan adalah wacana yang berisi komunikasi bersemuka antara dua orang atau lebih. Richard yang dikutip oleh Jumadi (2005:41) memberikan beberapa hal tentang tujuan percakapan, yakni sebagai pertukaran informasi, memelihara tali persahabatan sosial dan kekerabatan negosiasi status dan pengambilan keputusan serta pelaksanaan tindak bersama. Itulah sebabnya Richard (dalam Jumadi 2005:41) menyatakan bahwa salah satu pendekatan analisis fungsi bahasa dalam percakapan adalah teori tindak tutur. Sebuah percakapan baru akan efektif jika telah jelas konteks berlangsungnya sebuah penuturan.

Tindak tutur adalah tuturan dari seseorang yang bersifat psikologis dan yang dilihat dari makna tindakan dalam tuturannya itu. Serangkaian tindak tutur akan membentuk suatu peristiwa tutur (speech event). Lalu, tindak tutut dan peristiwa tutur ini menjadi dua gejala yang terdapat pada satu proses, yakni proses komunikasi. Menurut Searle (dalam Rani dkk, 2000:136), dalam komunikasi bahasa terdapat tindak tutur, Ia berpendapat bahwa komunikasi bahasa bukan sekedar lambang, kata, atau kalimat yang berwujud perilaku tindak tutur. Sebagaimana komunikasi bahasa yang dapat berwujud pernyataan, pertanyaan, dan perintah, maka tindak tutur dapat pula berwujud pernyataan, pertanyaan dan perintah.

Peneliti ingin mendeskripsikan fungsi tindak tutur dan persuasi yang digunakan perawat dalam melayani pasien. Hal tersebut menjadi alasan peneliti mengambil judul Bentuk Tindak Tutur persuasi Perawat dan Pasien di puskesmas Banua Lawas Kabupaten Tabalong. Peneliti lebih menekankan penelitian ini kepada objek kajian proses tindak tutur para perawat yang ada di puskesmas Banua Lawas Kabupaten Tabalong tersebut.

\section{METODE}

Pendekatan yang digunakan dalam penelitian ini adalah pendekatan kualitatif. Pendekatan kualitatif ini mudah diadaptasi dengan realitas yang beragam dan saling berinteraksi. Juga dinilai lebih sensitif segala aspek dan perubahan yang saling dipengaruhi yang akan dihadapi peneliti. 
Pendekatan kualitatif lebih mementingkan proses daripada hasil. Dalam pelaksanaan penelitian, khususnya pengumpulan data lebih diutamakan pada prosesnya. Pendekatan deskripsi kualitatif dilakukan setelah memperoleh data tentang bentuk persuasi yang digunakan perawat dan pasian di puskesmas Banua Lawas.

Disebut pendekatan kualitatif karena penelitian ini memiliki beberapa karekteristik. Menurut Guba dan Lincoln dalam Alwasilah (2005: 104-105) karekteristik tersebut dipaparkan berikut ini.

a. Latar alamiah

Suatu objek mesti dilihat dalam konteks yang alami, dan pengamatan juga akan mempengaruhi yang akan diamati, karena itu untuk mendapatkan pemahaman yang maksimal keseluruhan objek itu harus diamati.

b. Manusia sebagai instrumen

Cukup teritorial penelitian luas mempertontonkan interaksi saling mempengaruhi dengan tingkatan yang berbeda. Instrumen konvensional yang a priori dan disiapkan terlebih dahulu oleh si peneliti atau pesanan tidak akan sanggup beradaptasi secara fleksibel dengan realitas yang beragam. Hanya manusia yang sanggup menyesuaikan diri dan berinteraksi secara tuntas dengan fenomena yang sedang dipelajari.

c. Pemanfaatan pengetahuan non-proposisional

Peneliti naturalistis melegitimasi penggunaan intuisi, perasaan, firasat, dan pengetahuan lain yang tak terbahaskan selain pengetahuan proposisional banyak dipergunakan dalam proses interaksi antara penelitian dan responden. Penelitian ini juga banyak dipergunakan dalam proses interaksi antara penelitian dan responden. Pengetahuan itu juga banyak diperoleh dari responden terutama sewaktu peneliti mengintip nilai-nilai, kepercayaan, dan sikap yang tersembunyi pada responden.

d. Metode-metode kualitatif

Metode ini lebih mudah diadaptasikan dengan realitas yang be-ragam dan berinteraksi. Dinilai lebih sensitif terhadap segala aspek dan perubahan yang saling mempengaruhi yang akan dihadapi peneliti.

e. Sampel purposif

Pemilihan sampel secara purposif atau teoretis karena peneliti ingin meningkatkan cakupan dan jarak data yang dicari demi mendapatkan realitas yang berbagai-bagai, sehingga segala temuan akan terlandaskan secara lebih mantap karena prosesnya malibatkan kondisi dan nilai lokal yang semuanya saling mempengaruhi.

f. Analisis data secara induktif

Analisis data bersifat induktif, maksudnya data dianalisis melalui proses yang berlangsung dari fakta (data) ke teori. Bukan dari teori ke fakta (data). Setiap data tindak tutur perawat dan 
pasien dianalisis kemudian dibandingkan dengan teori. Metode ini memungkinkan peneliti mengedintifikasi realitas yang berbagai-bagai di lapangan, membentuk interaksi antara peneliti dan responden lebih eksplisit, nampak, mudah dilakukan, dan memungkinkan identifikasi aspek-aspek yang saling mempengaruhi.

Ruang yang diteliti merupakan ruang sebagai latar ilmiah merupakan tempat terjadinya interaksi antara perawat dalam melayani pasien di Puskesmas Banua Lawas Kabupaten Tablong yang menghasilkan tindak tutur secara ilmiah. Peran peneliti bertindak sebagai instrumen utama yang memahami permasalahan tindak tutur yang terjadi. Peneliti berusaha mendeskripsikan data tindak tutur yang diperoleh berdasarkan gejala yang diperoleh di lapangan.

Pendeskripsian dilakukan setelah memperoleh data tentang tindak tutur perawat dalam melayani pasien. Serta bentuk persuasi yang digunakan perawat saat melayani pasien di puskesmas Banua Lawas.

Pemerolehan data diusahakan pada setiap observasi, dan perekam. Pusat perhatian penelitian ini adalah fungsi tindak tutur perawat dan pasien di puskesmas Banua Lawas, dan fungsi bentuk persuasi yang digunakan perawat dan pasien di puskesmas Banua Lawas.

Penelitian ini menggunakan jenis penelitian pragmatik. Jenis penelitian pragmatik dipilih peneliti karena ini adalah penelitian yang termasuk dalam kajian studi pragmatik yang bertujuan untuk mengkaji fungsi tindak tutur dan bentuk persuasi. Jenis penelitian ini digunakan untuk mengkaji fungsi dan bentuk persuasi dari tuturan-tuturan antara perawat dan pasien di puskesmas Banua Lawas.

Penelitian tentang tuturan perawat dan pasien saat melayani pasien di puskesmas Banua Lawas. Berkaitan dengan suatu gejala kebahasaan yang sifatnya alamiah. Artinya, data yang dikumpulkan dari lingkungan bersifat yang nyata dan situasi alami, yaitu tuturan perawat dengan pasien.

Metode yang digunakan dalam penelitian ini yaitu metode deskriptif. Hal ini disebabkan karena data yang terkumpul dianalisis dan dipaparkan secara deskriptif. Metode yang digunakan dalam tahap penyedian data yaitu metode simak (pengamatan/observasi). Dalam hal ini, Mahsun (2005:218) mengatakan sebagai berikut.

Metode simak adalah metode yang digunakan dalam penyediaan data dengan cara peneliti melakukan penyimakan penggunaan bahasa. Metode ini memiliki teknik dasar yaitu teknik sadap. Dikatakan demikian karena dalam praktik penelitian sesungguhnya penyimakan itu dilakukan dengan menyadap pemakaian bahasa dari informan.

Dalam penelitian ini, peneliti bertindak sebagai instrumen sekaligus sebagai pengumpul data dan kedudukannya sebagai pengamat penuh atas segala hal yang berkaitan dengan masalah yang akan diteliti. Menurut, Moleong (2000:35) kedudukan peneliti dalam penelitian kualitatif sekaligus 
merupakan perencanaan, pelaksanaan pengumpulan data, analisis, penafsiran data, dan akhirnya menjadi pelapor hasil penelitian.

Lokasi yang dipilih pada penelitian ini adalah di puskesmas Banua Lawas Kabupaten Tabalong. Data dalam penelitian ini berwujud tuturan perawat dan pasien di puskesmas Banua Lawas yang mengandung tindak tutur dan bentuk persuasi. Sumber data utama dalam penelitian kualitatif ialah kata-kata, dan kalimat atau tuturan-tuturan antara perawat dan pasian di puskesmas Banua Lawas Kabupaten Tabalong yang mengandung tindak tutur; deklarasi, representatif, ekspresif, direktif, dan komisif, serta bentuk persuasi. Data dalam tuturan ini meliputi data dalam bentuk percakapan-percakapan antara perawat dan pasien.

Sumber data utama dalam penelitian kualitatif ialah kata-kata, dan tindakan selebihnya adalah data tambahan seperti dokumen, dan lain-lain (Lofland, dalam Moleong, 2000: 112). Sumber data pada penelitian ini adalah bentuk persuasi yang digunakan perawat dalam melayani pasien. Dokumen tertulis yang merupakan hasil transkip dari tuturan-tuturan antara perawat dan pasien.

Instrumen dalam penelitian ini berupa kalimat yang dituturkan perawat dan pasien. Diterjemahkan dalam bahasa Indonesia, terjemahan tersebut diklasifikasikan berdasarkan rumusan masalah. Cara ini dilakukan agar mendapat data yang lengkap dan akurat. Dengan demikian, hasil dari deskripsi penelitian ini dapat lebih terjamin, terpercaya dan dianggap sahih kebenarannya.

Prosedur yang digunakan dalam pengumpulan data pada penelitian ini adalah dengan menggunakan metode simak (pengamatan/observasi). Mahsun (2005:218) mengatakan sebagai berikut.

metode simak adalah metode yang digunakan dalam penyediaan data dengan cara peneliti melakukan penyimakan penggunaan bahasa. Metode ini memiliki teknik dasar yaitu teknik sadap. Dikatakan demikian karena dalam praktik penelitian sesungguhnya penyimakan itu dilakukan dengan penyadapan pemakaian bahasa dan informan. Pada penelitian ini peneliti menggunakan metode simak dan diikuti dengan teknik lanjutan; simak bebas libat cakap, teknik catat dan rekam.

a. Simak bebas libat cakap maksudnya si peneliti hanya berperan sebagai pengamat penggunaan bahasa tanpa terlibat dalam peristiwa tuturan yang bahasanya sedang diteliti.

b. Teknik catat maksudnya si peneliti melakukan pencatatan data ketika menerapkan metode simak.

c. Teknik rekam maksudnya si peneliti melakukan perekaman data ketika menerapkan metode simak.

Mahsun (2007:253) mendefinisikan analisis data merupakan upaya yang dilakukan untuk mengklasifikasi dan mengelompokkan data. Pada penelitian ini langkah-langkah yang dilakukan untuk menganalisis data, yaitu: 
a) Mendeskripsikan tuturan-tuturan antara perawat dan pasien di puskesmas Banua Lawas Kabupaten Tabalong dalam bentuk transkip percakapan.

b) Menafsirkan atau menganalisis seluruh tuturan-tuturan antara perawat dan pasien yang telah diperoleh di puskesmas Banua Lawas Kabupaten Tabalong.
c) Mengklasifikasi tuturan-tuturan antara perawat dan pasien di puskesmas Banua Lawas Kabupaten Tabalong sesuai dengan tujuan penelitian.

d) Mengelompokkan jenis tuturan-tuturan antara perawat dan pasien di puskesmas Banua Lawas Kabupaten Tabalong yang mengandung jenis fungsi tindak tutur dan bentuk persuasi.

\section{Hasil dan Pembahasan \\ Bentuk Persuasi}

Persuasi merupakan suatu seni dalam berbahasa yang bertujuan untuk menyakinkan seseorang agar melakukan sesuatu yang dikehendaki oleh pembicara. Dalam komunikasi dikenal dengan komunikasi persuasi, yakni komunikasi yang bertujuan untuk menyakinkan seseorang agar melakukan sesuatu yang dikehendaki pembicara. Terdapat berbagai macam teknik-teknik yang digunakan dalam persuasi yaitu rasionalisasi, identifikasi, sugesti, kompensasi, konformitas, pengganti, dan proyeksi.

\section{Rasionalisasi}

Rasionalisasi sebagai sebuah teknik dapat dibatasi sebagai suatu proses penggunaan akal untuk memberikan suatu dasar pembenaran kepada suatu persoalan. Rasionalisasi sebenarnya memperlihatkan sesuatu yang tampaknya dapat diterima oleh akal sehat. Rasionalisasi dalam persuasi akan berlangsung dengan baik bila pembicara mengentahui yang menjadi kebutuhan dan keinginan hadirin, serta sikap dan keyakinan mereka. Bantuk persuasi ini juga digunakan perawat dalam melayani pasien.

Tuturan antara perawat dan pasien pada wacana berikut terdapat tuturan persuasi dalam bentuk rasionalisasi terdapat dalam wacana berikut.

Perawat : "Jangan ditekuk batis pian bila duduk. Dibawa guring aj. Karena batis pian kaya ini makanya tangan pian bangkak. Cairannya menumpuk di sini. Ibarat batis tu, ini batis yang begantung. Jadi cairannya turun ke daerah yang rendah. Makanya bengkak.”(1) (Jangan ditekuk kaki Bapak kalau sedang duduk. Dibawa tidur saja. Karena kaki Bapak seperti ini makanya tangan bapak bengkak. Cairannya menumpuk di sini. Ibarat kaki, ini kaki yang tergantung. Jadi cairannya turun ke daerah yang rendah.) 


$$
\text { Pasien : "Inggih.”(2) }
$$

(Konteks : dituturkan ketika perawat berada di dalam ruang isolasi)

Tuturan percakapan di atas terdapat pada kutipan (1) yang dituturkan oleh perawat berisi persuasi rasionalisasi. Perawat memberikan tuturan tersebut dengan hukum sebab akibat. Yaitu karena pasien menekuk kaki ketika duduk, sehingga menyebabkan tangan bengkak. Perawat melakukan tindak pembenaran atas yang dituturkan. Dengan membuat sebuah asumsi agar pernyataan dapat diterima oleh pasien.

\section{Identifikasi}

Bentuk pesuasi identifikasi merupakan kunci keberhasilan pembicara. Agar dapat berjalan sebagaimana diharapkan haruslah diciptakan dasar umum yang sama. Dalam hal ini yakni antara perawat dan pasien. Perawat harus berusaha untuk menciptakan suatu dasar umum yang sama. Yakni bahwa mereka adalah orang yang sama-sama berada di Puskesmas tersebut. Perawat bertugas untuk membantu demi kesehatan pasien. Pasien memberikan informasi yang berkaitan dengan kesehatannya.

Tuturan antara perawat dan pasien pada wacana berikut terdapat tuturan persuasi dalam bentuk identifikasi terdapat dalam wacana berikut.

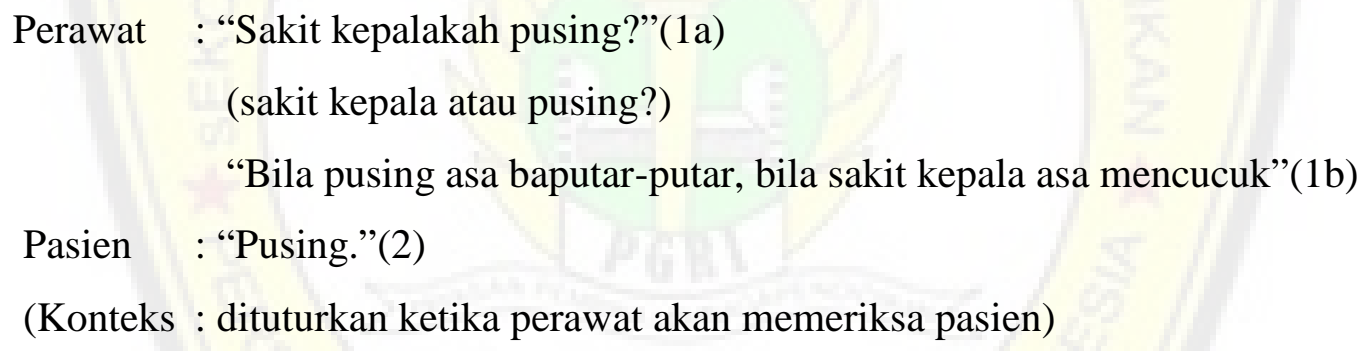

Tuturan percakapan di atas terdapat pada tuturan (1b) yang dituturkan oleh perawat berisi persuasi identifikasi. Tuturan yang dituturkan oleh perawat terdapat pada kalimat "Bila pusing asa baputar-putar, bila sakit kepala asa mencucuk." Tuturan perawat tersebut menggambarkan bahwa seorang perawat yang sedang melakukan identifikasi kepada pasien maupun keluarga pasien. Tujuannya tidak lain untuk mempercepat proses penyembuhan pasien. Sehingga tidak terhambat karena kurangnya informasi yang didapatkan. Dapat dilihat dalam tuturan tersebut bahwa perawat menanyakan tentang keluhan yang dirasakan oleh pasien. Tetapi karena pasien kurang mengerti sehingga perawat melakukan identifikasi dengan cara merincikan atau memperjelas pertanyaan yang diajukan. Hal ini, memudahkan pasien untuk menangkap arti sebuah tuturan. Sehingga tidak ada kesulitan dalam interaksi antara perawat dan pasien. Perawat melakukan tuturan tersebut untuk mencari informasi demi kelancaran proses pengobatan pasien. Sehingga diperlukan kerja sama yang baik antara perawat dan pasien. 


\section{Kompensasi}

Kompensasi adalah suatu tindakan atau suatu hasil dari usaha untuk mencari suatu pengganti bagi suatu hal yang tidak dapat diterima, atau suatu sikap keadaan yang tidak dapat dipertahankan. Perawat mendorong pasien untuk melakukan suatu tindakan atau perbuatan lain yang diinginkan oleh perawat dengan menunjukan bahwa pasien memiliki kemampuan untuk itu.

Tuturan antara perawat dan pasien pada wacana berikut terdapat tuturan persuasi dalam bentuk kompensasi terdapat dalam wacana berikut.

$$
\begin{aligned}
\text { Perawat } \quad \text { : 'Ibu balurus setumat tangan pian. Ini kena penyakitnya."(1) } \\
\text { (Ibu tangannya diluruskan sebentar, ini kena penyakitnya.) }
\end{aligned}
$$$$
\text { Pasien : "Inggih.”(2) }
$$

$$
\text { (Ya.) }
$$

(Konteks: dituturkan ketika perawat akan menyuntik pasien)

Tuturan percakapan di atas terdapat pada tuturan (1) yang dituturkan oleh perawat berisi persuasi kompensasi. Persuasi kompensasi yang dituturkan oleh perawat berupa tuturan perawat yang menyatakan bahwa pasien tersebut mampu meluruskan tangan. Walaupun dia merasa nyaman dengan menekuk tangan tersebut, tetapi perawat yakin bahwa pasien tersebut bisa melakukan penggantian posisi tangan. Tindakan yang dilakukan sebelum memperlambat proses penyembuhan, karena penyakit itu ada didaerah tangan beliau.

Tuturan persuasi dalam bentuk kompensasi terdapat pula pada percakapan berikut.

Perawat : "Batis pian diluruskan aja dulu jangan dilipat lah.”(1)

(Kaki Bapak diluruskan saja dulu jangan ditekuk ya)

Pasien : "Iya."(2)

(Ya)

(Konteks : Percakapan dilakukan ketika perawat masuk ruangan)

Tuturan percakapan di atas terdapat pada tuturan (1) yang dituturkan oleh perawat berisi persuasi kompensasi. Persuasi kompensasi yang dituturkan oleh perawat, yaitu "Batis pian diluruskan aja dulu jangan dilipat lah.” yang dituturkan oleh perawat kepada pasien mendorong pasien untuk melakukan sesuatu yang dikehendaki perawat yaitu untuk meluruskan kaki pasien agar jangan ditekuk, walaupun sebenarnya perawat tahu bahwa posisi kaki pasien ditekuk membuat pasien merasa nyaman. Tetapi kaki pasien ditekuk menghambat proses penyembuhan pasien. tetapi perawat yakin bahwa pasien memiliki kemampuan untuk mengganti posisi kaki tersebut

\section{Penggantian}

Penggantian suatu proses yang berusaha menggantikan suatu maksud atau hal yang lain. Dalam penggantian ini, pembicara berusaha meyakinkan hadirin untuk mengalihkan sesuatu obyek atau tujuan tertentu kepada suatu tujuan lain. Maksudnya di sini, perawat menyakinkan pasien 
untuk mengalihkan suatu tujuan tertentu ke tujuan yang lain, atau suatu tindakan tertentu ke tindakan yang lain.

Tuturan antara perawat dan pasien pada wacana berikut terdapat tuturan persuasi dalam bentuk penggantian terdapat dalam wacana berikut.

Perawat : "Bu suntik dulu lah, Ibu berbalik ke sana dulu, kalau bisa ditahan dulu batuknya! Berapa hari Ibu ini Pak.”(1)

(Ibu suntik dulu ya, berbalik ke sana dulu, kalau bisa ditahan dulu batuknya! Berapa hari Ibu ini Pak)

Kel. Pasien : "Sudah lima hari.”(2)

Perawat : "Sudah lima hari lah, Istirahat Bu lah!”(3)

(Sudah lima hari ya, istirahat ya bu!)

(Konteks : dituturkan ketika perawat akan menyuntik pasien)

Tuturan percakapan di atas pada percakapan tuturan (1) yang dituturkan oleh perawat berisi tentang tuturan persuasi penggantian. Perawat berusaha mengubah posisi tidur pasien dari menghadap ke kiri menjadi menghadap ke kanan. Agar memudahkan untuk menyuntikan. Selain itu perawat juga minta pasien untuk menahan batuk. Hal ini sesuai dengan tujuan dari persuasi penggantian, yaitu bertujuan untuk menggantikan suatu tindakan tertentu ke tindakan yang lain.

\section{Konformitas}

Suatu keinginan atau suatu tindakan untuk membuat diri serupa dengan sesuatu hal yang lain. Dengan kata lain yakni suatu mekanisme untuk menyesuaikan diri untuk mencocokan diri dengan sesuatu yang diinginkan. Dalam persuasi, orang yang menggunakan teknik ini untuk menyesuaikan dirinya dengan orang yang dipersuasi. Dalam konformitas, pembicara memperlihatkan bahwa dirinya mampu berbuat dan bertindak sebagai para hadirin.

Tuturan antara perawat dan pasien pada wacana berikut terdapat tuturan persuasi dalam bentuk konformitas terdapat dalam wacana berikut.

Pasien : : Aduh padihnya."

(aduh pedih sekali.)

Perawat : "Padih banarkah?"

(Ekspresi muka seperti merasakan pedih.)

Hi ih ini dasar padih obatnya. Tahan duu lah. Sambil digosok pakai kapas.!

(Konteks : dituturkan ketika perawat sedang menyuntik pasien)

Tuturan percakapan perawat seolah-olah merasakan yang dirasakan oleh pasien. Perawat melakukan persuasi konformitas yaitu bisa berbuat dan bertindak seperti pasien. Hal itu dapat dibuktikan dengan ekspresi perawat yang seolah-olah merasakan pedih karena obat yang 
disuntikkan. Itu menunjukkan bahwa dengan tindakan tersbut perawat telah ikut menyelami perasaan pasien sehingga bisa lebih dekat dan tidak ada jarak dengan pasien.

\section{Proyeksi}

Suatu teknik untuk menjadikan sesuatu yang tadinya subyek menjadi obyek. Teknik ini mirip dengna teknik penggantian dan kompensasi. Kesalahan yang dilakukan seseorang dilemparkan kepada orang lain, bahwa orang lain itu yang melakukan.

Tuturan antara perawat dan pasien pada wacana berikut terdapat tuturan persuasi dalam bentuk proyeksi terdapat dalam wacana berikut.

Pasien : : Obat ini gasan apa?Berapa manabusi?"(1)

(Obat ini untuk apa?Berapa menebusnya)

Perawat : "Nah ulun kada tahu. Pian langsung aja ke apoteknya ja."(2)

(Saya tidak tahu. Ibu lamgsung ke apotek.)

(Konteks : dituturkan ketika pasien menunjukkan resep obat)

Tuturan percakapan di atas yang dituturkan oleh perawat pada kutipan (2) dapat dilihat bahwa ketika keluarga pasien bertanya tentang resep yang diberikan oleh dokter dikarenakan dia tidak mengerti. Perawat itu melemparkan ke apotek, dikarenakan dia juga tidak mengerti dengan yang ditulis di dalam resep tersebut. Hal ini menunjukkan bahwa perawat melemparkan pertanyaan tersebut, dia berusaha agar dirinya tidak terlihat tidak tahu di hadapan pasien. Sehingga dia berusaha untuk menyelamatkan muka.

Dengan demikian bentuk-bentuk persuasi yang digunakan oleh perawat dapt membantu proses komunikasi kepda pasien maupun kelaurga pasien yang terkadang mengalami hambatan. Dengan adanya teknik-teknik ini perawat merasa lebih nyaman dalam berkomunikasi.

\section{Penutup}

Simpulan

Berdasarkan paparan hasil analisis data tuturan antara perawat dan pasien di Puskesmas Banua Lawas Kabupaten Tablong mengenai tindak tutur yang terungkap dalam dalam percakapan tersebut diperoleh kesimpulan sebagai berikut.

a) Bentuk-bentuk persuasi yang digunakan perawat dalam tuturan perawat dan pasien di Puskesmas Banua Lawas Kabupaten Tablong terbagi menjadi tujuh jenis, yaitu persuasi rasionalisasi, persuasi identifikasi, persuasi sugesti, persuasi kompensasi, persuasi penggantian, persuasi konformitas, dan persuasi proyeksi.

b) Rasionalisasi sebagai sebuah teknik dapat dibatasi sebagai suatu proses penggunaan akal untuk memberikan suatu dasar pembenaran kepada suatu persoalan, diantara dasar atau alasan 
itu tidak merupakan sebab langsung dari masalah itu. Rasionalisasi memperlihatkan sesuatu yang tampaknya dapat diterima oleh akal sehat.

c) Identifikasi haruslah diciptakan dasar umunya yang sama. Bila terdapat suatu konflik antara pembicara dan hadirin, maka pembicara harus berusaha mengaburkan situasi konflik berbeda. Agar dapat berjalan sebagaimana diharapkan haruslah diciptakan dasar umum yang sama. Maksudnya, perawat harus berusaha untuk menciptakan suatu dasar umum yang sama, yakni bahwa mereka adalah orang yang sama-sama berada di Puskesmas Banua Lawas Kabupaten Tablong tersebut. Perawat bertugas untuk membantu demi kesehatan pasien dan pasien memberikan informasi yang berkaitan dengan kesehatannya.

d) Sugesti suatu usaha untuk membujuk atau mempengaruhi orang lain untuk menerima suatu keyakinan atau pendirian tertentu tanpa memberi suatu dasar kepercayaan yang logis pada orang yang ingin dipengaruhi. sugesti yang diberikan oleh perawat kepada pasien berupa katakata dengan nada suara yang lembut dan bijaksana, sehingga membuat pasien merasa nyaman.

e) Kompensasi suatu tindakan atau hasil dari usaha untuk mencari suatu pengganti bagi hal yang tidak dapat diterima, atau suatu sikap keadaan yang tidak dapat dipertahankan. kompensasi pada tuturan perawat mendorong pasien untuk melakukan suatu tindakan atau perbuatan lain yang diinginkan oleh perawat dengan menunjukan bahwa pasien memiliki kemampuan untuk itu.

f) Penggantian suatu proses yang berusaha menggantikan suatu maksud atau hal yang lain. Dalam penggantian ini, pembicara berusaha meyakinkan hadirin untuk mengalihkan sesuatu obyek atau tujuan tertentu kepada suatu tujuan lain. Maksudnya, perawat menyakinkan pasien untuk mengalihkan suatu tujuan tertentu ke tujuan yang lain, atau suatu tindakan tertentu ke tindakan yang lain.

g) Konformitas suatu keinginan atau tindakan untuk membuat dirinya serupa dengan suatu hal yang lain. Konformitas adalah suatu mekanisme mental untuk menyesuaikan diri atau mencocokkan diri dengan sesuatu yang diinginkan. memperlihatkan bahwa dirinya mampu berbuat dan bertindak sebagai para hadirin.

h) Proyeksi suatu teknik untuk menjadikan sesuatu yang tadinya adalah subyek menjadi objek. Maksudnya di sini jika seseorang diminta untuk mendeskripsikan seseorang yang tidak disenangi, ia akan berusaha mendeskripsikan hal-hal yang baik mengenai dirinya. Kesalahan yang dilakukan seseorang dilemparkan kepada orang lain, bahwa orang lain itu yang melakukan. 


\section{Saran}

Diharapkan Penelitian tentang tindak tutur ini lebih dikembangkan lagi oleh peneliti selanjutnya agar tujuan yang diinginkan bisa tercapai.

\section{Daftar Rujukan}

Alwasilah, A Chaedar. 1986. Pokok Kualitatif: Dasar-dasar Merancang dan Melakukan Penelitian Kualitatif. Bandung: Angkasa.

Alwi, Hasan, dkk. 2007. Kamus Besar Bahasa Indonesia Edisi Ketiga. Jakarta: Balai Pustaka.

Chaer, Abdul, dan Agustina, Lionie. 2004. Sosiolinguistik: Perkenalan Awal. Jakarta: Rineka Cipta.

Etikasari, Dian. 2012. Tindak Tutur Direktif dalam Wacana kelas. Malang: Universitas Negeri Malang.

Faisal, Putri Manggala. 2010. Prinsip Kerjasama dan Kesantunan Berbahasa Perawat dalam Menghadapi Pasien yang Mengalami Gangguan Jiwa di RS. J. Prof. dr. Soeroyo Magelang. Diponegoro: Universitas Ilmu Budaya.

Finoza, Lamudin. 2000. Komposisi Bahasa Indonesia untuk Mahasiswa Nonjurusan Bahasa. Jakarta: Mawar Gempita.

Hutagalung, Sari. 2014. Kesopanan Berbahasa dalam Tindak Tutur Direktif Perawat Bangsal Bedah Rumah Sakit dr. M. Djamil Padang. Sumatera Barat: Universitas Bung Hatta. 